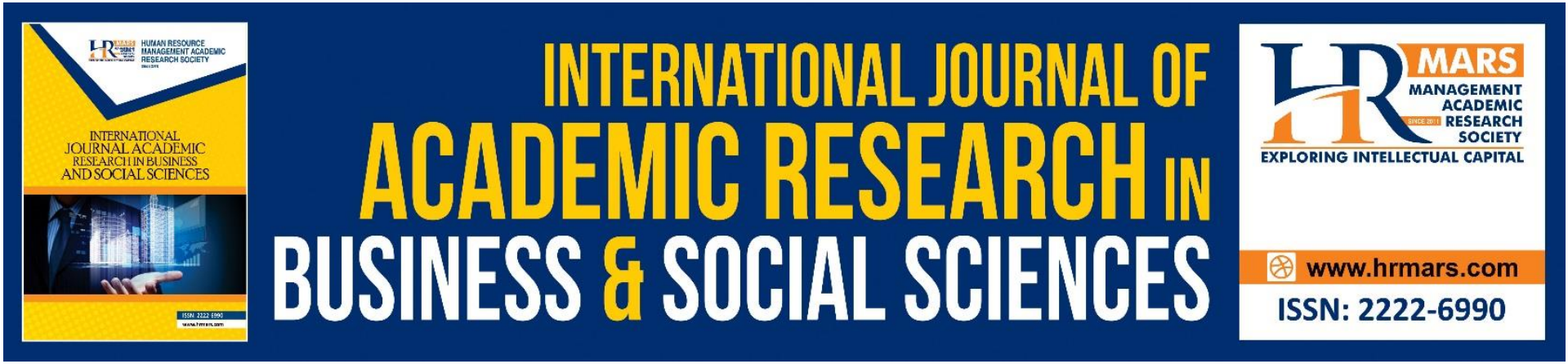

\title{
Basic Public Welfare Research Project of Zhejiang Province A Review of the Emissions Scandals and their Impact on Volkswagen
}

Popa Nicoleta-Elena, Meiyu Fang

To Link this Article: http://dx.doi.org/10.6007/IJARBSS/v10-i12/8264

DOI:10.6007/IJARBSS/v10-i12/8264

Received: 03 November 2020, Revised: 28 November 2020, Accepted: 30 November 2020

Published Online: 15 December 2020

In-Text Citation: (Nicoleta-Elena \& Fang, 2020)

To Cite this Article: Nicoleta-Elena, P., \& Fang, M. (2020). Basic Public Welfare Research Project of Zhejiang Province A Review of the Emissions Scandals and their Impact on Volkswagen. International Journal of Academic Research in Business and Social Sciences, 10(12), 91-100.

Copyright: (C) 2020 The Author(s)

Published by Human Resource Management Academic Research Society (www.hrmars.com)

This article is published under the Creative Commons Attribution (CC BY 4.0) license. Anyone may reproduce, distribute, translate and create derivative works of this article (for both commercial and non-commercial purposes), subject to full attribution to the original publication and authors. The full terms of this license may be seen

at: http://creativecommons.org/licences/by/4.0/legalcode

Vol. 10, No. 12, 2020, Pg. 91 - 100

Full Terms \& Conditions of access and use can be found at http://hrmars.com/index.php/pages/detail/publication-ethics 


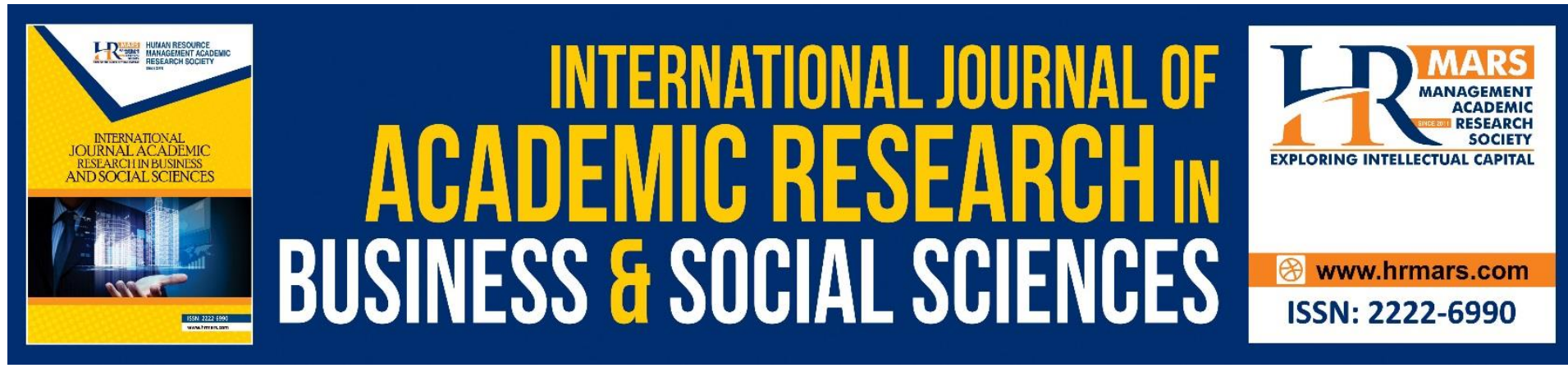

\title{
Basic Public Welfare Research Project of Zhejiang Province A Review of the Emissions Scandals and their Impact on Volkswagen
}

\author{
Popa Nicoleta-Elena1, a 方美玉 Meiyu Fang ${ }^{1, b}$ \\ Zhejiang University of Science and Technology, Hangzhou 311300, China. \\ Email: ${ }^{a}$ nico_popa94@yahoo.com, ${ }^{b}$ myfang180@163.com
}

\begin{abstract}
Five years ago, the automobile world was shaken by one of the biggest scandals that started in the US and slowly spread to different corners of the world. This phenomenon got to be known as the "diesel dupe", "diesel gate" or simply Volkswagen's emissions scandal. What were the repercussions of these calumnious actions and how have they affected Volkswagen's image, its sale performance and costumer trust after admitting that nearly 11 million cars worldwide were equipped with the so-called "defeat device"?
\end{abstract}

Keywords: Automobile World, Emissions Scandal, Volkswagen, Sale Performance, Costumer Trusts.

\section{Introduction}

September 2015 marks the date when Volkswagen Group started one of its most ferocious battles and not against its competitors but against its own defamatory actions that have gravely agitated the automobile industry. The Environmental Protection Agency (EPA) has discovered that a high number of vehicles that were sold in America had a so-called "defeat device" fitted in the diesel engines that could detect when they were being tested and were designed to change the performance accordingly to improve results, EPA (2015). In more words, this sophisticated software was implemented a test sensor and could easily monitor speed, engine operation, air pressure and the position of the steering wheel. During a vehicle test under laboratory condition, the vehicle normally is situated on a stationary test rig.

The device was designed so well that could sense the test scenario and whenever tested would enter a safety mode, making the engine minimize to a low its power and performance. Once the vehicle was back on the road the safety mode would switch off and the engine would run at its normal power and performance, which in this case was emitting nitrogen oxide pollutants above 40 times the level of pollution allowed in the United States, Ibid (2015).

What started as a small flame in the US, turned into a misting fire that expanded worldwide. Countries such as Germany, Italy, France, UK, Canada or South Korea, couldn't turn a blind eye at what was happening in the US and begun their own investigation, Russel (2015). Gradually environmental groups, regulators or politicians around the world started 
questioning VW's emission testing validity. According to EPA data, there were discovered more than 500.000 cars fitted with the device only in the US, including not only VW models such as Jetta, Beetle, Golf and Passat but also some of its owned brands such as Audi, Clifford (2019). As the scandal was deepening so were Volkswagen's intentions to come clean, therefore the group affirmed that the software was installed in 11 million diesel vehicles worldwide, including 590,000 in the US and 8 million in Europe. It is of great importance to point out that the scandal had a different outcome in the US than in Europe, all due to the fact that European Testing rules are not as strict as the ones in the US.

According to the UK trade body for the car industry, SMMT affirmed that, "The EU operates a fundamentally different system to the US, with all European tests performed in strict conditions as required by EU law and witnessed by a government-appointed independent approval agency", Ibid (2019). This statement did nothing but point out that European testing rules are outdated and they should be improved and stricter. Along with the scandal people around the world became aware of the inefficiency of the European testing rules when it comes to diesel cars, which came as a blast for the diesel market, which was already passing a problematic period.

\section{Volkswagen's Emissions Scandal Consequences on the Diesel Market}

Many articles have been published all voicing the same idea, Volkswagen has landed a big blow for the diesel market with its emissions scandal. The diesel engine cars were already undergoing a decrease in demand when VW's scandal added more sorrow to the situation. Diesel cars were already put in a negative light by two things, the environmental concerned costumers and the insurance process. As more and more people were getting involved in protecting the environment, they were shutting down diesel cars because of the high level of emissions that they produce. Concerning the insurance process, diesel cars are $15 \%$ more costly to insure than the petrol cars, which makes them more expensive.

Many experts were expressing concerns, trying to decipher what this slowdown meant and anticipating that this indeed could be the end of the global diesel market. The automotive expert at consultants Vendigital, Richard Gane, was declaring, "The revelations are likely to lead to a sharp fall in demand for diesel engine cars". In the US the situation wasn't troubling considering that at that time the diesel car market share represented $1 \%$ of all new car sales, contradictory to this was the situation in Europe where the impact was expected to be more disastrous. Max Warburton (2018), automobile research analyst at Berstein Research stated that: "The move against VW is going to act as a catalyst to speed up the fall in diesel market share in Europe and halt it in the US". Nothing could have been more devastating for Europe, after investing billions of euros in diesel technology having one big aim, which was to discover a cleaner and environmentally friendly diesel engine, Ibid (2018). The breakout of the diesel scandal did nothing but indicate that those billions were thrown away to no good use.

It was not at all surprising to observe that following the Diesel gate scandal in 2015, Standard and Poor's credit rating agency announced that the market share of diesel engine vehicles dipped below $50 \%$ for the first time in ten years reaching to $48.9 \%$ in 2016 and continue its fall to $42.7 \%$ in 2017 . As the automobile market powered by a diesel engine was in decline before the VW scandal, once the scandal was made public, the downfall was accelerated. 
With a stained reputation and a new series of penalties and rules for the diesel engine cars the future doesn't seem too promising, Paul (2015).

Opposing the diesel market share that was gradually shrinking, the petrol market was slowly taking the lead overtaking the diesel car market share for the first time since 2009, electric vehicles are also slowly becoming a trend on the European Market, increasing their market share yearly. What has come of Diesel's market share on Europe's biggest markets? Figure 1 outlines very well the dissension of diesel engine cars on Europe's five biggest markets: Germany, UK, France, Spain and Italy, Ibid (2015).

Figure 1 - Diesel share of new car sales, percentage.

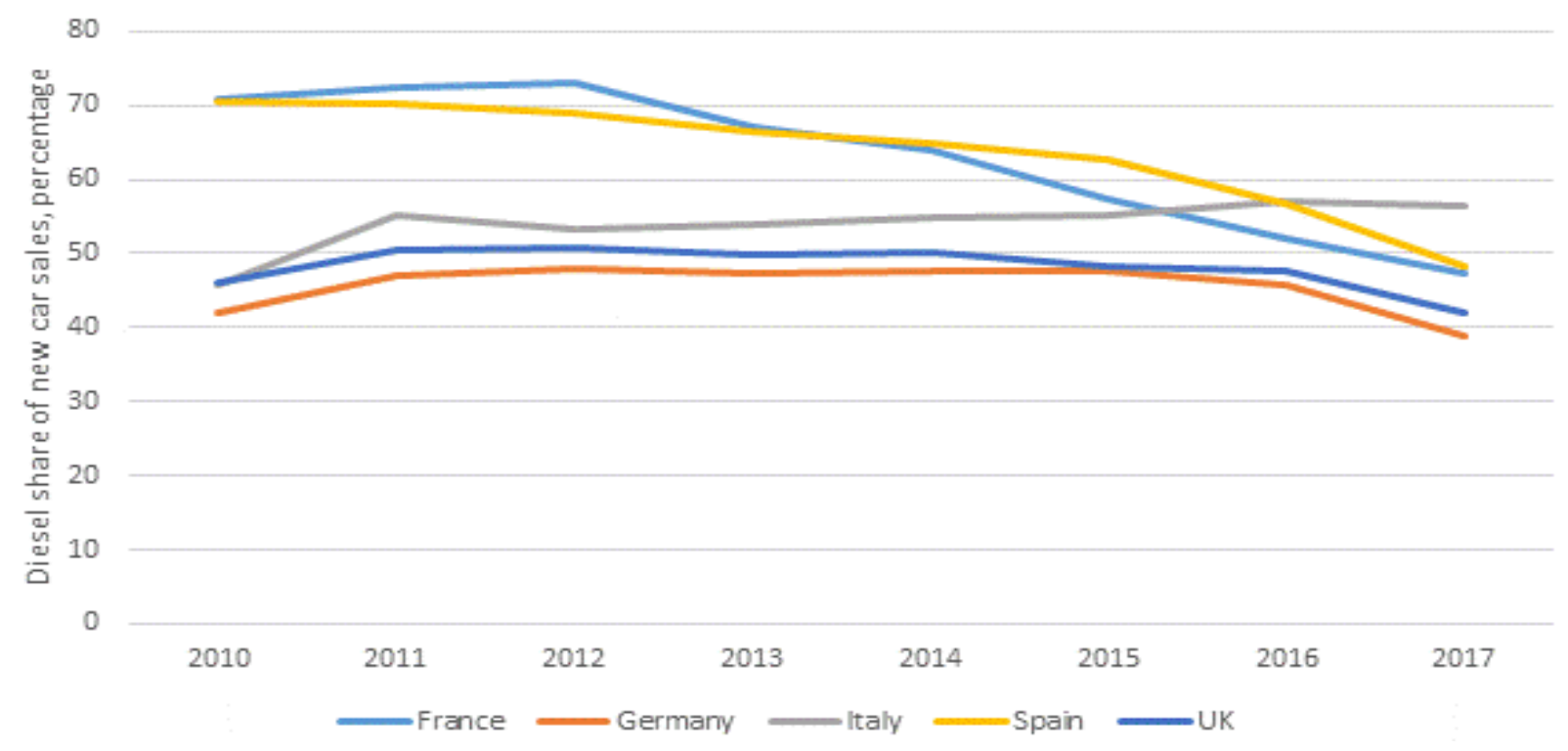

Sources - ACEA, CCFA, KBA, ANFIA, ANFAC, SMMT.

The above graphic shows very detailed that the downfall of the diesel market share has started before the scandal was made public, but it was a smooth, a slow process. After 2015 it is easy to see that the decline was very pronounced and happened also faster than in the previous years. Italy is the only country where the diesel cars market share has increased in 2016 and had only a small decline the following year. What makes Italy different from the other four countries, probably the lack of regulatory measures in what concerns diesel engine. At that time regulatory measures were being introduced in Germany, France, Spain and UK; Italy remained an exception of those rules. In Germany the diesel share went as low as 39\% in 2017, showed no sign of rising in the future as in 2019 it came down to only $30 \%$. In France diesel also reached its lowest point in 2017 after 17 years shrinking below 50\%, being overtaken by the petrol car market.

In Spain the diesel market has met more sorrow than in any European country, the decline has been more significant than anywhere else from $70 \%$ market share falling below $50 \%$ just in a period of one-year 2016 to 2017. The UK adopted as well the negative trend of diesel decrease, when the shares dipped in 2017 to $42 \%$ and later below $40 \%$ from $48 \%$ in 2016. What does the future hold for the diesel engine vehicles; many experts predict that the future doesn't seem too bright for this type of vehicles. There are reports that imply that around 
2030 the diesel market share would have dipped as low as $30 \%$ and it is not hard to understand why, people are becoming more aware of the climate and protection of the environment, moreover the petrol cars have the highest demand on the market while the electric vehicles demand are in a continuous growth.

\section{Regaining Costumer Trust and Liberation from the Emissions Fiasco (Corporate Sanitization)}

There is nothing that attracts more attention than a big scandal. General Motors as well as Toyota had their own defamation situations, the first tied to damaged ignition switches and the second due to issues with accidental acceleration from sticky pedals. Both groups managed to control the situation and recover from the scandals even if life losses were involved in these cases, Julia (2016). When Volkswagen's cheating allegations were made public 5 years ago the question that everyone was asking was if the Group would surpass the difficult times that were showing ahead.

After sales plunged and the stock value diminished the future of Volkswagen was uncertain. There were many scandals that agitated the automobile industry and not only and many of them proved that a bounce back is possible. The situation looked very gloom for $\mathrm{VW}$, suffering reputation damage, having its CEO resign short time after the situation was made public, leaving the Group to drown it's in own toxicity or so it seemed, Keith (2015). Richard Torrenzano, CEO of the Torrenzano Group an institution specialized in crisis management for corporations stated that 'How can VW polish themselves off and move on? It's not a simple matter. They need a strategy to move through this carefully. It's a matter of credibility. Cheating is a terrible sin". There was hope for Volkswagen after all to recover, and maybe even to reach its aim to become the biggest carmaker in the world.

As anticipated the market share as well as the profits plunged around $20 \%$ for $\mathrm{VW}$ after the DIESEL GATE scandal became the main topic for discussion in Europe and US, Kalyeena (2015). Volkswagen shares were down to $18.6 \%$ at Europe's close according to different sources while assumptions were made that in US the Group could face civil penalties up to $40000 \$$ for each vehicle that didn't comply with the federal clean air rules, for only US the fines were thought to be up to 18 billion overall. Shares were slipping and so were the car sales especially for the Volkswagen marque cars, the profit came down to nearly $20 \%$ at the beginning of 2016 . Indisputable 2016 has been a demanding one for the Group, but not everything was lost, VW Motors (2016).

Furthermore, it is true that sales for the Volkswagen Marque cars were at their lowest but the non-marques managed to somehow limit the damage and create somehow a balance. While VW brand cars registered an immense loss, with their profits falling from 514 million euro to 73 million euro, the Group's owned brands such as Porsche, Skoda and Seat proved to be life changing in this situation due to their high sales and accomplishing profits. The group's revenue fell up to $5 \%$ in 2016 but according to their statements the fall wasn't solely caused by the diesel scandal but also because of the unstable exchange rate, Jae (2016). Coming down from a profit of 4 billion euro in 2015 to 3.2 billion Euros in 2016 highlights the fact that the scandal wasn't as disastrous as predicted for the group. Regarding this unexpected outcome many experts pointed out that costumers weren't very concerned about the emission scandal as thought. 
With lawsuits opened around the world the circumstances seemed to be promising for the carmaker as Warwick's Business School Professor Christian Stadler (2017) declares that most of Volkswagen's costumers 'don't care about the environmental issues that much. What they care about is quality and value for money", Personally, I wouldn't say that the Group had it easy as the fines they had to cover were excessive, but what I think is promising and positive about this situation is the fact that their image wasn't so altered as to lose many potential consumers. The ridiculous thing in this situation is the fact that even at its lowest point Volkswagen was back on track to become the world's biggest car manufacturer as its competitors also suffered a decrease in sales. 2018 was the year that marked the so-called coronation, as Volkswagen was proclaimed by many sources the world's biggest automaker, VW Motors (2018). Many factors have contributed to reaching this ideal, but I think the ones that impacted the most were the following:

$>$ Volkswagen cooperated with the authorities and tried their best to even the losses of many costumers.

$>$ They buried the past by creating a new logo and started looking towards the future to innovation the electric era.

$>$ The position and high sales on the world's biggest market, China have kept the brand from collapsing.

\section{Volkswagen takes Responsibility for the Diesel Gate Scandal}

The final compensation settled by the US District Court Judge, Charles Breyer for VW's cheating on diesel-emissions was $14.7 \$$ billion according to different publishing sources. To redeem itself in front of its American costumers the Group has created a buyback and compensation program of $\$ 10$ billion for its 2.0-liter cars and additional a program of 1.2 $\$$ billion was established for the owners and lessees of 3.0-liter diesel models, Marc (2019). Therefore, all costumers had the right to choose if they wanted to sell back their cars to the company under the government negotiated compensation agreement or keep them and receive a free emission fix plus compensations.

The buyback and compensation program as well as the repairs and fix program were available for the following vehicles:

2.0-liter Volkswagen and Audi TDI models, for vehicles purchased before September 17, 2015, for all three generations of the 2.0-liter turbo-diesel.

$>$ 3.0-liter Volkswagen and Audi TDI and Porsche diesel models, for 2009-2012 Audi Q7 and Volkswagen Touareg with Generation one engine also for generation two models in between 2013-2016.

The program created was very solid as it included even those who owned an affected vehicle but sold or traded it before the scandal was made public as well as $2.7 \$$ billion were added to help fund projects that reduce nitrogen-oxide emissions. Moreover, Bosch the supplier of the emissions software also created its own program of 327.5 million to support the car owner and lessees, Business Insider (2016). The penalties went deeper than financial compensation as few executives, engineers and the former general manager of the Group have been sentenced to prison time and had to cover big fines. After the US charges other countries opened their own researches and asked the Volkswagen for 
compensations. Ironic is that the company wasn't as giving with its German costumers after plenty of lawsuits were opened there a settlement of 830 million Euro was reached, Deutsche Welle, (2016)

Since 2015 it has been reported that Volkswagen has paid more than 30 billion euro worldwide all for compensation, fines are legal costs. Many costumers were aided by the situation and might have increased their trust in the Group but as one side was somehow pleased many workers of Volkswagen were going through their own sorrow as jobs had to be cut along the years.

\section{Volkswagen, The Focus on Electric Vehicles and Logo Changes}

Volkswagen tries very hard to leave behind its scandalous cheating days and begin a new chapter. What better way to do that than changing the emblem that represents them, the famous ' $W$ ' logo? Along the years the official logo has undergone small changes, but now represents a new phase for Volkswagen Group, a transition to e-mobility, with more focus on data, on brand design and visual language, Bloomberg (2019).

The new logo shows itself to be simpler, lighter looking and slimmer. The executive director of Volkswagen Design, Klaus Bischoff, (2019) explains what the essence of the lighter concept is for the Volkswagen: "light is the new chromium. This way we want to focus on warmth and humanity." The logo has already been added on its Atlas Cross Sport model sold in U.S in 2020 and it has made its debut in the new era in 2019 at the International Motor Show in Frankfurt along with the brand's full electric ID.3 vehicle.

The actions of Volkswagen seeking to reshape its image worldwide have been interminable, the Group has put behind its diesel days and concentrates on new ambitions such as becoming the head of the world's electric cars. Volkswagen' design executive Klaus Bischoff explained the significance of this change: 'This rebrand also brings Volkswagen into the digital era, transforming our classic logo into a trademark that is easily displayed digitally on devices and applications", Volkswagen Group (2019).

Figure 2 - Volkswagen new logo

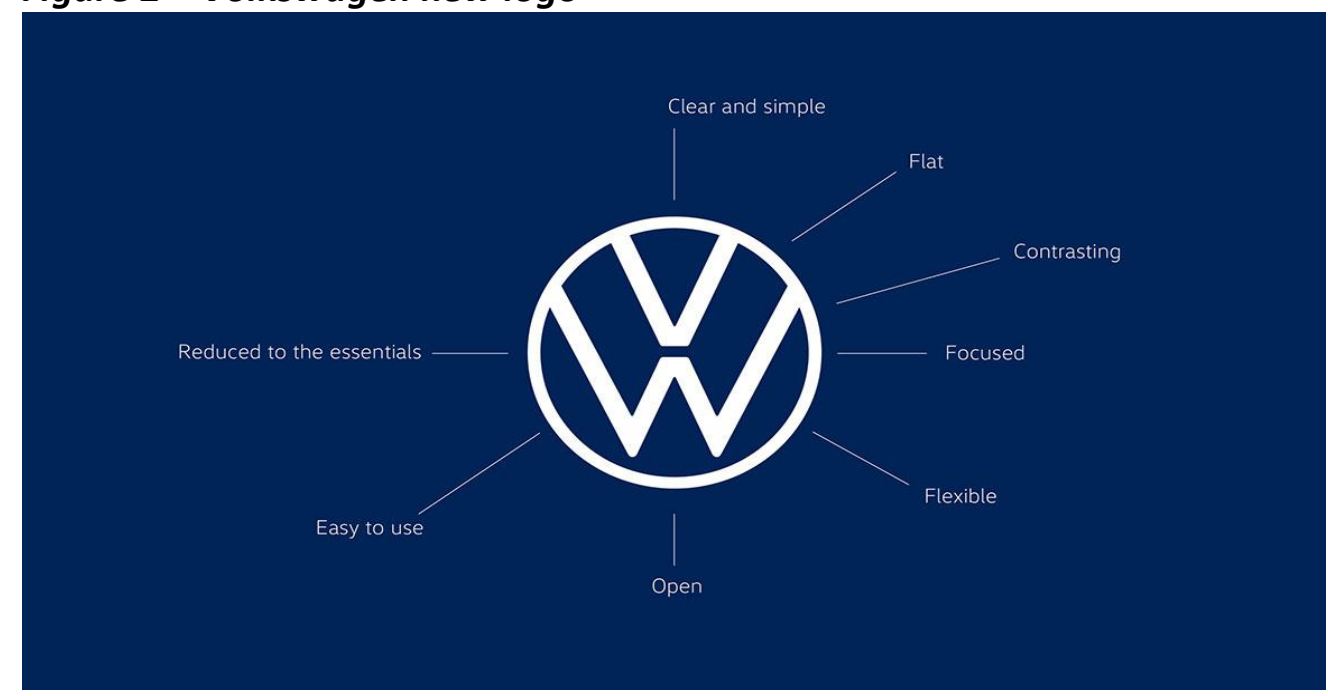

Source: Volkswagen.com 
The new logo represents a transition, a transformation that will see a reborn Volkswagen concerned by climate and environment, and will see e-mobility a concept affordable for millions of people. As described by the group itself the essence of the New Volkswagen can be described as: fascinating, sustainable, reliable and affordable, Ibid (2019).

With new principles that set as central of attention the costumers, the digital media, a new attitude expressed by new brand designs, brand differentiation, full brand experience and global brand governance Volkswagen paints the future in shades of encouragement, hope and a valuable masterpiece.

\section{The Center of Strength for Volkswagen_Chinese Market}

While facing one of its biggest storms, Volkswagen has found its safe haven, China. While around the world sales were slumping, lawsuits and buybacks costs were initiated, the Chinese market remained Volkswagen's steady place. VW's scandal had small repercussions in what concerns China and all due to the fact that Volkswagen doesn't sell many diesel cars there. Actually, the only diesel engine vehicles sold in China by Volkswagen are imported from Europe and sold mainly to taxi companies. As the scandal was spreading and Volkswagen's image around the world was disintegrating, Chinese costumers were still purchasing their VW vehicles like nothing was happening, Volkswagen Group (2019). According to the survey made on tencent.cn in 2020, in which took part 71 people, Chinese males and females, when asked if they have heard about the VW's emissions scandal, $71.83 \%$ have affirmed that they are unaware of the scandal, TencentSurveys (2020). How much the scandal was mediatized in China remains a mystery but surprising is that when asked if after finding out about the scandal their view of the brand will change, $65 \%$ have had a negative answer.

Moreover, the same number of people were asked if they see Volkswagen as a trustworthy company, 63 people have given an affirmative answer. It is undeniable that the carmaker has its roots planted very deep in the Chinese land, even so there might arise a small issue in the future, concerning VW's concept of electrifying the automobile industry. When asked if they prefer a fuel car or an electric car, 63\% opted for the fuel powered car, the excitement for electric cars might not be as high as believed but there is definitely potential, and having an enlarged experience in China there is no doubt Volkswagen will manage to change the minds of its potential consumers.

According to different sources Volkswagen brand has sold 4,374,900 cars worldwide in 2016, an increase of $0.6 \%$ from its previous year. As sales have fallen in South America, Brazil and USA they have significantly increased in China, Asia Pacific and Central and Eastern Europe. In 2016 VW has sold more than two million cars in China which stands for more than $48 \%$ of the brand's world-wide sales. Volkswagen has reported that most of its $11.4 \%$ yearly growth is associated to the sales of its most popular models on the Chinese market: Lavida, Sagitar, Jetta and Santana sedans. Jurgen Stackmann (2017), Volkswagen's Brand Board Member for Sales at the time showed his gratitude towards the Middle Kingdom through his public statement: 'Thanks to the strong performance in China, deliveries by Volkswagen in September were noticeably higher than the previous year. Consequently, our deliveries for the period from January to September exceeded the 2015 level". 
INTERNATIONAL JOURNAL OF ACADEMIC RESEARCH IN BUSINESS AND SOCIAL SCIENCES

Vol. 10, No. 12, 2020, E-ISSN: 2222-6990 @ 2020 HRMARS

Table 1 - Overview of deliveries by the Volkswagen Passenger Cars Brands

\begin{tabular}{|l|l|l|l|l|l|l|}
\hline $\begin{array}{l}\text { Deliveries to } \\
\text { customers by } \\
\text { markets }\end{array}$ & $\begin{array}{l}\text { Septemb } \\
\text { er 2016 }\end{array}$ & $\begin{array}{l}\text { Septem } \\
\text { ber } \\
2015\end{array}$ & $\begin{array}{l}\text { Change } \\
(\%)\end{array}$ & $\begin{array}{l}\text { Jan. } \\
\text { Sep. 2016 }\end{array}$ & $\begin{array}{l}\text { Jan. }- \\
\text { Sep. 2015 }\end{array}$ & $\begin{array}{l}\text { Change } \\
(\%)\end{array}$ \\
\hline Europe & 160,400 & 158,000 & +1.6 & $1,288,400$ & $1,298,800$ & -0.8 \\
\hline $\begin{array}{l}\text { Western } \\
\text { Europe }\end{array}$ & 141,000 & 140,400 & +0.4 & $1,125,300$ & $1,146,800$ & -1.9 \\
\hline Germany & 48,300 & 49,100 & -1.5 & 431,800 & 448,500 & -3.7 \\
\hline $\begin{array}{l}\text { Central and } \\
\text { Eastern Europe }\end{array}$ & 19,400 & 17,600 & +10.4 & 163,100 & 152,000 & +7.3 \\
\hline Russia & 7,000 & 6,800 & +2.9 & 52,700 & 56,000 & -5.9 \\
\hline North America & 45,600 & 45,900 & -0.7 & 423,900 & 443,300 & -4.4 \\
\hline USA & 24,100 & 26,100 & -7.8 & 231,300 & 266,200 & -12.5 \\
\hline South America & 20,500 & 38,900 & -47.2 & 254,200 & 363,900 & -30.2 \\
\hline Brazil & 9,900 & 27,400 & -63.7 & 164,400 & 267,500 & -38.5 \\
\hline Asia-Pacific & 303,700 & 253,400 & +19.8 & $2,264,900$ & $2,077,100$ & +9.0 \\
\hline China & 288,800 & 235,300 & +22.8 & $2,133,100$ & $1,914,000$ & +11.4 \\
\hline Worldwide & 547,700 & 513,500 & +6.7 & $4,374,900$ & $4,349,600$ & $+\mathbf{0 . 6}$ \\
\hline
\end{tabular}

\section{Source: VolkswagenGroup}

A cooperation of 40 years, or simply a good market research the bond between Volkswagen and its Chinese costumers is almost unbreakable. China became Volkswagen's biggest and most important market along the years and the brand managed to gain popularity enjoying the top spot. The Group has more than 180 models in China produced locally and abroad, making sure they cover all sections of costumers with affordable VW passenger cars or fanciful Lamborghinis, to motorcycles or commercial vehicles, Ibid (2019).

\section{Conclusion}

While many experts have envisioned Volkswagen's downfall in the automobile industry the company proved itself to be the Phoenix of this industry as it rose from its ashes and became the world's largest car manufacturer. And that is not all, since its emissions scandal days Volkswagen has completely changed its perspective moving its focus towards electric vehicles, having only aim which is to become the leader of the category. With a new logo, innovative car models and evolving technology the brand lays its highest hopes on the Chinese market to turn its ambition into reality. Volkswagen is the real example of strength and persistency, emissions scandal, US trade war with China, Corona Virus and other 
hardships along the years have affected the Group and its brands but always managed to overcome them all.

\section{References}

Clifford, A. (2019). "Everything you need to know about VW Diesel-Emissions Scandal". Car and Driver. December 4.

Jae, C. J. (2016), "The Volkswagen emissions scandal and its aftermath". Global Business and Organizational Excellence. 38(4), 6, 15.

Jasper, J. (2019), "Volkswagen emissions scandal: mass lawsuit opens in Germany". The Guardian. September 30.

Julia, K. (2016). "VW profits down 20\% after diesel emissions scandal". The Guardian, May 31.

Kalyeena, M. (2015). "Volkswagen stock drops $20 \%$ on US diesel recall probe". CNBC, September 21.

Keith, B. (2015). "VW's recall troubles may have little effect on China, its largest market". The New York Times, September 21.

Marc, T. (2019). "These are the Biggest Automakers in the World". Wheels.ca, August 20.

Paul, R. (2015). "Volkswagen has plunged 50\%. Will it ever recover?", CNN Business, September 25.

Russel, H. (2015), "Volkswagen: The scandal explained". BBC News, December 10.

VolkswagenGroup. (2016), "Volkswagen brand reports rise in worldwide deliveries from January to September". Clasicos Al Volante, October 16.

VolkswagenGroup. (2019), "That's what new Volkswagen is all about". Volkswagen Group, September 10. 